\title{
Morphometric Study of Rat Sciatic Nerve Recovery after Three Nerve Repair Techniques: Epineural Suture, Polyethylene Glycol Hydrogel and Fibrin Sealant
}

\author{
Estudio Morfométrico de la Recuperación del Nervio Ciático de Rata después de Tres Técnicas \\ de Reparación Nerviosa: Sutura Epineural, Hidrogel de Polietilenglicol y Sellante de Fibrina
}

\author{
Goncharuk Oleksii O. ${ }^{1}$; Savosko Serhii I. ${ }^{2}$; Petriv Taras I. ${ }^{1}$; Medvediev Volodymyr V. ${ }^{1}$ \& Tsymbaliuk Vitaly I. ${ }^{1}$
}

GONCHARUK, O. O.; SAVOSKO, S. I.; PETRIV, T. I.; MEDVEDIEV, V. V. \& TSYMBALIUK, V. I. Morphometric study of rat sciatic nerve recovery after three nerve repair techniques: Epineural suture, polyethylene glycol hydrogel and fibrin sealant. Int. J. Morphol., 39(3):677-682, 2021.

SUMMARY: The effectiveness of microsurgical technique has a direct impact on the recovery of the injured peripheral nerve. The aim of our study was to investigate the result of sciatic nerve regeneration in rats after complete neurotomy and after nerve repair techniques including: 1) epineural suture; 2) polyethylene glycol hydrogel (PEG) (DuraSeal); 3) fibrin sealant (Tisseel). The cross-section of distal sciatic nerve was studied at 14th, 30th and 60th days after nerve repair. Morphometry of myelinated nerve fibers in the distal stump of the sciatic nerve was performed. A significant increase in the number of myelinated nerve fibers was found, especially between 14 and 30 days. The density of myelinated nerve fibers in the distal stump at day 60 was significantly higher after using nerve repair technique including PEG and fibrin versus epineural suture $(29.2 \%$ and $32.1 \%$ versus $21.5 \%, \mathrm{P}<0.05)$, and a higher level of remyelination of nerve fibers observed in the group with PEG. On day 60, complete elimination of PEG and fibrin sealant was not observed, encapsulation was found around the clusters of hydrogel. Thereby, three peripheral nerve repair techniques were equally effective, only with the use of PEG remyelination of nerve fibers was increasing.

KEY WORDS: Sciatic nerve; Regeneration; Epineural suture; Polyethylene glycol; Fibrin glue.

\section{INTRODUCTION}

Microsurgical repair of a damaged nerve is a problem of current interest, as nerve regeneration is slow, at a low rate, often not achieving sufficient muscle reinnervation and functional recovery. The critical area in the damaged nerve is the suture area, because if the connection of the nerve stumps is failed, it does not allow the regeneration of nerve fibers in the distal stump of the nerve to occur (Khalifeh et al., 2019). Another critical factor is the method and strength of the connection of nerve stumps, number of stitches in case of autografting (Gaiovych et al., 2019).

The gold standard for peripheral nerve neuroraphy is the epineural suture. This is a relatively simple and nonalternative way of connecting nerve stumps if there is no major nerve defect (Kornfeld et al., 2019), although other nerve coaptation techniques have been considered (Molotkovets et al., 2020). Problems associated with the inability of nerve to regenerate are the failure of the epineural suture and its rupture, which leads to repeated microsurgical operations. To avoid this disadvantage, the possibility of using additional adhesive sealants around the suture, such as hydrogels based on polyethylene glycol (PEG) and fibrin (fibrin glue, FG) (Sexton et al., 2012) is considered.

PEG is a water-soluble polymer of ethylene oxide, a biocompatible semi-adhesive gel-like substance that can be used in tissue repair as a substrate for cell adhesion. PEG coatings were first developed to minimize the surface adhesion of plasma proteins to materials (Kim et al., 2005), later PEG forms were improved to form a microenvironment for cells, surgical barriers, etc. (Puttaswarmy et al., 2018). A synthetic analogue of PEG hydrogel (DuraSeal) is increasingly used in neurosurgery (Lee et al., 2013).

\footnotetext{
${ }^{1}$ Department of Neurosurgery, Bogomolets National Medical University, Ukraine.

${ }^{2}$ Department of Histology \& Embryology, Bogomolets National Medical University, Ukraine.
} 
GONCHARUK, O. O.; SAVOSKO, S. I.; PETRIV, T. I.; MEDVEDIEV, V. V. \& TSYMBALIUK, V. I. Morphometric study of rat sciatic nerve recovery after three nerve repair techniques: Epineural suture, polyethylene glycol hydrogel and fibrin sealant. Int. J. Morphol., 39(3):677-682, 2021.

Autologous fibrin glue was originally the only available and easy to create tissue glue, but some technical circumstances of its preparation (centrifugation of blood components, addition of thrombin) prompted the development of a simpler form of use that would completely eliminate these disadvantages. Commercial fibrin gel has become the most commonly used gel in surgery, such as Tisseel (Isaacs et al., 2008).

Unlike suture materials, hydrogels are less traumatic, but the strength of nerve connections, biodegradation, and elimination of gels remain unclear (Isaacs et al.). PEG and FG can equally connect the nerve stumps; they do not interfere with nerve regeneration and should not cause connective tissue development, as fixation of the nerve with paraneural tissues impairs the efficiency of recovery (Tse \& Ko, 2012). In this paper, we consider the possibility of additional coaptation of damaged nerve stumps with polyethylene glycol (PEG) and fibrin glue (FG), counting on additional adhesion of the nerve sheath (epineurium) of the two stumps of the nerve.

The aim of this study was to evaluate the regeneration of sciatic nerve after microsurgical techniques including epineurial suture, PEG and FG.

\section{MATERIAL AND METHOD}

Experimental animals. The experiments were performed on white outbred male rats $(250 \pm 25 \mathrm{~g}, 5-6$ months $)$. Rats were divided into groups of 5 animals in the group: group 1 - control (intact rats), group 2 -sham-operated animals, where only approach to the sciatic nerve was done without nerve damage, group 3 - animals, where sciatic nerve was transected and then connected with an epineural suture"end-to-end" (4-6 epineural sutures with polyamide thread $10 / 0)$, group 4 -animals, where sciatic nerve was transected and then connected with polyethylene glycol hydrogel (PEG) (DuraSeal®, Covidien LLC, USA) and 2 "fixating" epineural sutures, group 5 -animals, where sciatic nerve was transected and then connected with fibrin glue (FG) (Tisseel) and 2 "fixating" epineural sutures.

DuraSeal@ dural sealant system is composed of two solutions: 1) a polyethylene glycol (PEG) ester solution and 2) a trilysine amine solution (referred to as the blue and the clear precursors, respectively). Tisseel sealant system is composed of two solutions: 1) Human fibrinogen, Synthetic Aprotinin and 2) a Human thrombin, Calcium chloride dihydrate.
The surgery was performed under anesthesia (xylazine $15 \mathrm{mg} / \mathrm{kg}$ and ketamine $70 \mathrm{mg} / \mathrm{kg}$, intraperitoneally). Firstly approach to the sciatic nerve was made, then the nerve was completely cut, after that specific operation depending on the group it was performed, and in the end suturing the wound in layers with monofilament polyamide thread 4/0 was done.

Bioethics. All experimental procedures were conducted according of current standards of bioethics (EU Directive 2010/63/EU "on the protection of animals used for scientific purposes" (1986), European Convention for the Protection of Vertebrate Animals Used for Experimental and Scientific Purposes (1986), Law of Ukraine of February 21, 2006 No. 3447-IV "About protection of animals against ill treatment" (2006)). The protocol of the study was approved by the bioethical commission of Bogomolets National Medical University (protocol 113).

Light Microscopy. Longitudinal cryo-sections were made from the suture area, the material was pre-fixed in $10 \%$ phosphate buffered formalin. Slices stained by PicroSirius Red (0.5 g Direct Red 80 (Magnacol Ltd, UK) in $500 \mathrm{ml}$ of saturated picric acid) dehydrated and placed in the medium (Merck, Germany).

Distal sciatic nerve was fixed in $2.5 \%$ solution of glutaraldehyde in phosphate buffer with $1 \%$ osmium tetrachloride, dehydrated in increasing concentrations of ethanol and acetone. The distal nerve samples we embedded in the Epone-Araldite mixture. To get the ultrathin slices, we applied an ultratome (Reihart). The semi-thin sections were stained with toluidine blue (Hayat, 2000), and then were studied under a light microscope (Olympus BX 51) for histological and morphometrical examination.

For morphometric examination, Carl Zeiss software (AxioVision SE64 Rel.4.9.1) and a camera attachment were used. Distal sciatic nerve samples for each rat were examined at high $(\times 1000)$ magnification. The mean numerical density of the myelinated axons was estimated in photo $\left(216 \times 138 \mu \mathrm{m}\right.$, average $\left.0.03 \mathrm{~mm}^{2}\right)$, amount of sampling photo are 10-15 (2/3-3/4 of cross-section of nerve). The mean diameter $(\mu \mathrm{m})$ of the myelinated axons was estimated by average of large and small diameters per individual fiber.

The statistical analysis was done by StatPlus version 7.0 (Microsoft). The data are expressed as mean \pm standard error of mean (SEM). The results were analyzed and compared using analysis of variance (one-way ANOVA) followed by Bonferroni's post hoc test. Differences were considered significant at $\mathrm{P}<0.05$. 


\section{RESULTS AND DISCUSSION}

Nerve suture area. The sutures were surrounded by connective tissue and this has increased the focal thickness of the epineurium (Table I). Between days 14 and 60, nerve thickness, which was calculated on longitudinal histological sections, increased statistically (neuroma formation and epineurial connective tissue enlargement). PEG encapsulation (focal clusters of PEG from 90 to $1600 \mu \mathrm{m}$ ) was detected, and focal clusters of fibrin were smaller and multifocal (focal clusters of FG from 100 to $200 \mu \mathrm{m}$ ). In the PEG and FG group epineurial thickness increased by 60th day, but remained within the statistical error compared to the epineural suture group (ES-group) (Table I). There were no inflammatory leukocyte infiltration in areas with PEG and FG.

Fascicles changes. At the site of the suture, the integrity of the fascicles was changed, and regenerative neuroma was formed. In all studied samples, the distal stump of the nerve retained the fascicular structure. PEG and FG did not affect the change of nerve fascicles. The thickness of the distal stump of the nerve also did not change.

Regeneration of myelinated nerve fibers in distal stump. In the group of sham operated animals, no difference in density and diameter of myelinated nerve fibers was detected both with control and in three periods of the experiment. On days 14, 30, and 60 after repair, thin regenerating myelinated nerve fibers were found in the distal stump of the sciatic nerve (Fig. 1). In the ES-group, the number of nerve fibers increased between 14 and 60 days (Table I). The diameter of the myelinated nerve fibers did not differ. At 60th day, the appearance of thick fibers was detected, but this did not affect the overall assessment (average diameter of most fibers was 4-6 $\mu \mathrm{m}$, whereas in the control 8-10 $\mu \mathrm{m})$.

In the group with PEG (PEG-group), the density of nerve fibers increased significantly compared with the ESgroup at 30 and 60 days. The number of nerve fibers in distal stump significantly increased compared to day 14 . The diameter of myelinated nerve fibers also increased, especially by day 30 (the appearance of fibers up to $16 \mu \mathrm{m}$ in diameter, although 4-6 $\mu \mathrm{m}$ dominated), and the number of thin fibers further increased.

In the FG-group, the density of myelinated nerve fibers in distal stump significantly increased by 30 and 60 days, and the fiber diameter was significantly larger than in the epineural suture group by day 14 and was smaller by day 60 than in the PEG-group (most with a diameter of 4-6 $\mu \mathrm{m}$ at all periods; the fiber density did not differ relative to the PEG-group).

Table I. Morphometric data for rats sciatic nerve on 14, 30 and 60 day after neurorrhaphy.

\begin{tabular}{|c|c|c|c|c|c|c|}
\hline Parameter & Day & Control & Shame-operated & Epineural suture & PEG & FG \\
\hline Thickness of the & 14 & & - & $1534.1 \pm 222.6$ & $1560.1 \pm 148.9$ & $1598.9 \pm 179.3$ \\
\hline nerve in sutured & 30 & - & & $1943.7 \pm 63.1$ & $1619.3 \pm 102.2$ & $1542.2 \pm 133.3$ \\
\hline site $(\mu \mathrm{m})$ & 60 & & & 2260.8土165.2@ & $2261.5 \pm 101.9$ & $1997.0 \pm 80.8$ \\
\hline \multirow{3}{*}{$\begin{array}{l}\text { Thickness of the } \\
\text { distal nerve } \\
(\mu \mathrm{m})\end{array}$} & 14 & & $1122.8 \pm 53.3$ & $986.9 \pm 68.4$ & $1006.8 \pm 45.4$ & $1001.4 \pm 52.1$ \\
\hline & 30 & $1139.7 \pm 96.8$ & $1142.8 \pm 32.8$ & $992.7 \pm 27.0$ & $1017.8 \pm 87.1$ & $1208.1 \pm 172.2$ \\
\hline & 60 & & $1150.2 \pm 63.0$ & $1024.1 \pm 85.2$ & $1101.0 \pm 75.4$ & $985.4 \pm 57.6$ \\
\hline \multirow{3}{*}{$\begin{array}{l}\text { Number of } \\
\text { fascicle }\end{array}$} & 14 & & $2.6 \pm 0.2$ & $2.6 \pm 0.2$ & $2.8 \pm 0.2$ & $2.6 \pm 0.2$ \\
\hline & 30 & $2.8 \pm 0.3$ & $3.0 \pm 0.3$ & $2.8 \pm 0.2$ & $2.4 \pm 0.2$ & $3.0 \pm 0.3$ \\
\hline & 60 & & $2.8 \pm 0.2$ & $2.8 \pm 0.4$ & $3.0 \pm 0.4$ & $2.8 \pm 0.2$ \\
\hline \multirow{3}{*}{$\begin{array}{c}\text { Number } \\
\text { (fiber/test-zone }\end{array}$} & 14 & & $202.8 \pm 12.06$ & $25,29 \pm 1,77 *$ & $30,4 \pm 1,45^{*}$ & $31,7 \pm 1,47^{*}$ \\
\hline & 30 & $200.0 \pm 13.14$ & $197.4 \pm 10.71$ & $38.5 \pm 2.40^{*}$ & $48.5 \pm 2.78 * \wedge$ & $56.8 \pm 4.39 * \wedge$ \\
\hline & 60 & & $199.5 \pm 10.76$ & $43,15 \pm 2,04 *$ & $58,5 \pm 2,66^{* \wedge} @ * *$ & $64,2 \pm 2,20 * @ * *$ \\
\hline \multirow{3}{*}{$\begin{array}{c}\text { Density } \\
(\text { fiber/mm²) }\end{array}$} & 14 & & $5643.4 \pm 209.4$ & $720.6 \pm 48.5^{*}$ & $868.1 \pm 39.7 *$ & $905.4 \pm 40.2 *$ \\
\hline & 30 & $5703.6 \pm 256.0$ & $5734.4 \pm 211.4$ & $1076.8 \pm 61.7 *$ & 1384.7士77.6*^@ & 1618.8土121.7*^@ \\
\hline & 60 & & $5445.7 \pm 177.3$ & 1229.8土55.8*@ & 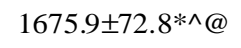 & 1829.8土60.1*^@ \\
\hline \multirow{2}{*}{$\begin{array}{c}\text { Diameter of } \\
\text { myelinated }\end{array}$} & 14 & & $15.16 \pm 0.37$ & $4,75 \pm 0,06$ & $5,20 \pm 0,15^{\wedge}$ & $5,54 \pm 0,18^{\wedge}$ \\
\hline & 30 & $15.28 \pm 0.36$ & $15.81 \pm 0.35$ & $4.82 \pm 0.05^{*}$ & $8.58 \pm 0.18 * \wedge$ & $5.23 \pm 0.06^{*}$ \\
\hline nerve fiber $(\mu \mathrm{m})$ & 60 & & $16.24 \pm 0.34$ & $6,20 \pm 0,12^{*}$ & $6,50 \pm 0,12 *$ & $5,74 \pm 0,27 *, * * *$ \\
\hline \multirow{3}{*}{$\begin{array}{c}\text { Myelin } \\
\text { thickness } \\
(\mu \mathrm{m})\end{array}$} & 14 & & $3.71 \pm 0.13$ & $0.74 \pm 0.02 *$ & $0.81 \pm 0.02 *$ & $0.82 \pm 0.02 *$ \\
\hline & 30 & $3.74 \pm 0.12$ & $3.72 \pm 0.18$ & $0.98 \pm 0.10 * @ * * *$ & 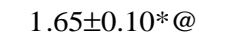 & $1.21 \pm 0.02 * @ * * *$ \\
\hline & 60 & & $3.78 \pm 0.15$ & $1.27 \pm 0.04 * @ * *$ & $1.34 \pm 0.04 * @ * *$ & $1.32 \pm 0.05 * @$ \\
\hline
\end{tabular}

Data expressed as mean $\pm \mathrm{SEM} * \mathrm{P}<0.05$ in comparison with the control and shame-operated group; ${ }^{\wedge} \mathrm{P}<0.05$ in comparison with the ES; @ in comparison with $14 \mathrm{day}$; ** in comparison with $1 \mathrm{~m}$; *** $\mathrm{P}<0.05$ in comparison with the PEG. 


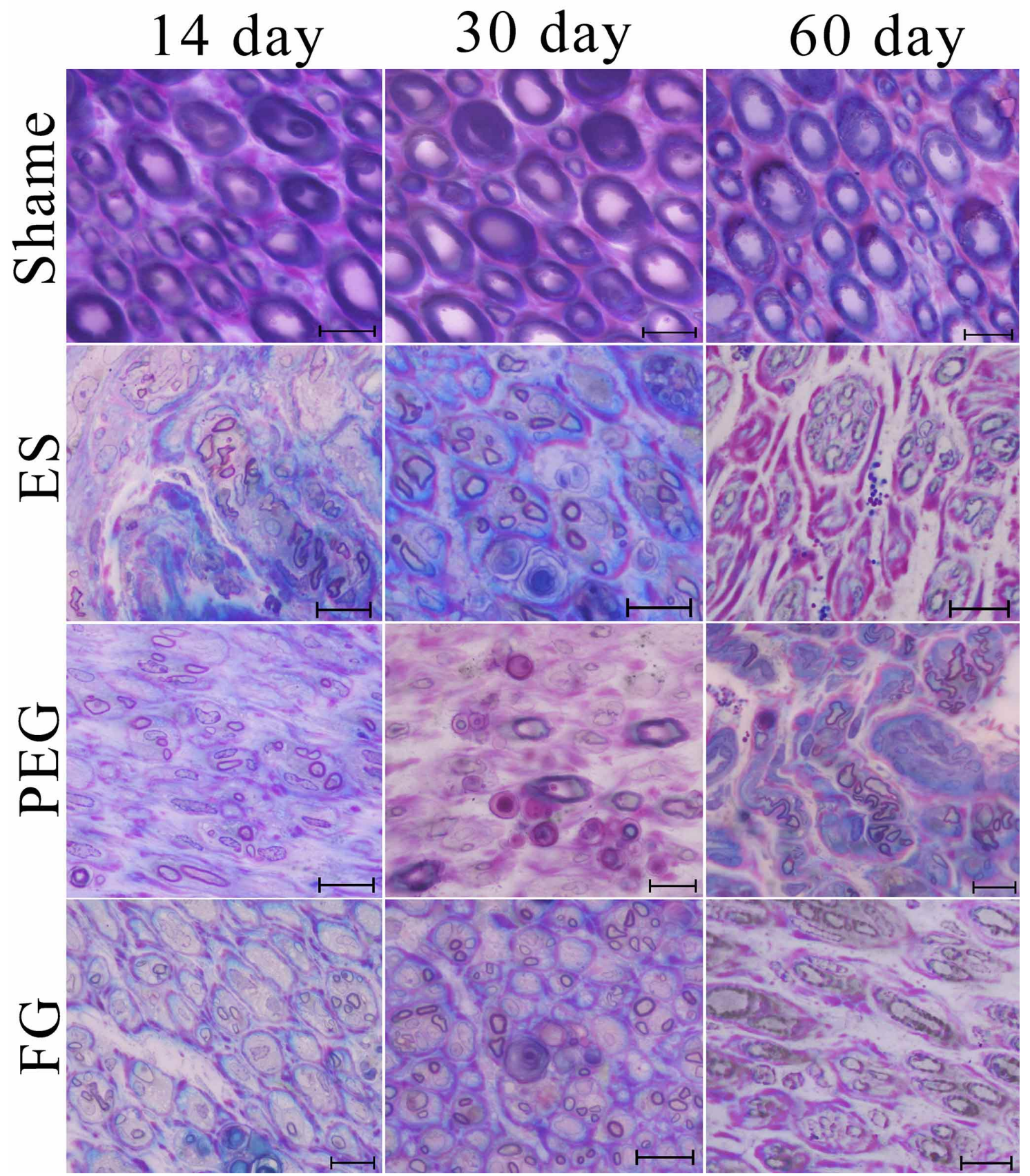

Fig. 1. Cross section of in distal sciatic nerve stained by M.A. Hayat method: SHAME - shame-operated; ES - epineurial suture; PEG - polyethylene glycol; FG - fibrin glue. Scale bar: $20 \mu \mathrm{m}$.

Morphometric analysis showed a significantly higher number of myelinated nerve fibers in the distal stump of sciatic nerve in PEG- and FG-group versus ESgroup at day $60(29.2 \%$ and $32.1 \%$ versus $21.5 \%$, P $<0.05$ ), and PEG contributed to the regeneration of larger fibers (with a thicker myelin sheath).

An increase in the thickness of the myelin sheath in nerve fibers was also revealed, when comparing 14 and
60 days in each group, the difference was 1.78, 1.65 and 1.65 times $(\mathrm{P}<0.05)$. Regeneration of larger-diameter myelinated fibers of a larger diameter (higher than $5.2 \mu \mathrm{m}$ ) on day 30 in the PEG-group suggests an accelerated growth and remyelination of myelin fibers in this group.

In general, in the distal stump of the sciatic nerve there was a partial preservation of endoneural elements (endoneural tubes) in three nerve repair techniques, no 
significant difference was found in the regeneration of nerve fibers, although PEG contributed to the regeneration of larger diameter myelinated fibers, indicating the acceleration of regeneration, similarly, the regeneration density increases after the application of FG.

There is interest in the development of surgical adhesives for gluing nerves, which would be non-toxic, biocompatible, had adhesion to epineurium and at the same time did not cause fibrotic changes and nerve fixation with paraneural tissues. The main purpose of their use is to reduce the trauma of the connecting nerve stumps. Substances in the form of glues and gels partially realize this task. This study compared nerve regeneration after neuroraphy with the use of 4-6 epineural sutures, and nerve repair techniques including 2 sutures withPEG and FG. The last two were still fixated with 2 sutures, because in our opinion the adhesive characteristics of PEG and FG are still insufficient for a strong connection of the nerve stumps. Similarly, other authors believe, in particular, the effect of combining PEG with spastin (Lin et al., 2019) or PEG with suture (Ghergherehchi et al., 2019) was better than PEG alone.

According to the results of the work, the coaptation of the transected sciatic nerve in 3 ways was equally sufficient for the formation of regenerative neuroma and regeneration of nerve fibers in the distal stump of the nerve. At day 60, focal PEG and FG remained, FG underwent greater elimination than PEG, and caused less connective tissue growth at the suture site. Importantly, the fascicular structure of the nerve and endoneural tubes in the distal stump of the nerve remained preserved, and no difference in the morphology of the distal nerve between the comparison groups was found. Preservation of endoneural tubes is important for nerve regeneration because regenerating nerve fibers have adhesion to collagen and endoneural fibroblasts, as well as to other extracellular matrix proteins. The absence of damaging effect on the nerve from PEG and FG, sufficient nerve fixation, and the acceleration of nerve fibers regeneration at day 60 after microsurgical nerve repair is an advantage over multiple nerve sutures.

Isaacs et al. also found no difference in nerve diameter, epineural changes, and perineural scarring between DuraSeal and fibrin, and in subsequent studies found no difference in the strength of the restored nerve after DuraSeal, Tisseel, and autologous fibrin. Sexton et $a l$. in a model of a nerve graft found an increase in the number of nerve fibers by $15 \%$ in the graft and distal nerve after the application of PEG. Lin et al. (2010) found no difference in nerve regeneration and electrophysiological values after suture and PEG (DuraSeal), instead the latter gave better results compared to fibrin glue. But due to sutures and PEG, the thickness of the nerve has increased, which is absent or at a lesser extent develops after the application of fibrin glue. PEG had a higher adhesive capacity compared to FG, so in the latter occurred a diastase (gap). After PEG, myelinated fibers of a larger diameter were regenerating, as described in later articles (Lin et al., 2019) and noted in our study. Moreover, there is evidence that acceleration of peripheral nerve regeneration after PEG administration prevents gastrocnemius muscle atrophy (Lin et al., 2019).

In conclusion, adhesive sealants based on PEG and fibrin can be an alternative to sutures in restoring peripheral nerves, it reduces coaptation time and trauma, creates an environment of glue around the injured nerve.

GONCHARUK, O. O.; SAVOSKO, S. I.; PETRIV, T. I.; MEDVEDIEV, V. V. \& TSYMBALIUK, V. I. Estudio morfométrico de la recuperación del nervio ciático de rata después de tres técnicas de reparación nerviosa: sutura epineural, hidrogel de polietilenglicol y sellante de fibrina. Int. J. Morphol., 39(3):677-682, 2021.

RESUMEN: La efectividad de la técnica microquirúrgica tiene un impacto directo en la recuperación del nervio periférico lesionado. El objetivo de nuestro estudio fue investigar el resultado de la regeneración del nervio ciático en ratas después de una neurotomía completa y después de técnicas de reparación nerviosa que incluyeron: 1) sutura epineural; 2) hidrogel de polietilenglicol (PEG) (DuraSeal); 3) sellante de fibrina (Tisseel). La sección transversal del nervio ciático distal se estudió a los 14, 30 y 60 días después de la reparación del nervio. Se realizó la morfometría de fibras nerviosas mielinizadas en el muñón distal del nervio ciático. Se observó un aumento significativo en el número de fibras nerviosas mielinizadas, especialmente entre los 14 y 30 días. La densidad de las fibras nerviosas mielinizadas en el muñón distal en el día 60 fue significativamente mayor después de usar una técnica de reparación nerviosa que incluye PEG y fibrina en comparación con la sutura epineural $(29,2 \%$ y $32,1 \%$ versus $21,5 \%$, $\mathrm{P}<0,05)$, y un mayor nivel de remielinización del nervio en fibras observadas en el grupo con PEG. El día 60, no se observó la eliminación completa de PEG y sellador de fibrina, se encontró encapsulación alrededor de los grupos de hidrogel. Por lo tanto, tres técnicas de reparación de nervios periféricos fueron igualmente efectivas, solo que aumentaba la remielinización de fibras nerviosas con PEG.

PALABRAS CLAVE: Nervio ciático; Regeneración; Sutura epineural; Polietilenglicol; Cola de fibrina. 


\section{REFERENCES}

Gaiovych, I.; Savosko, S.; Labunets, I.; Utko, N.; Makarenko, A. \& Chaikovsky, Y. Sciatic nerve regeneration after autografting and application of the bone marrow aspirate concentration. Georgian Med. News, (295):145-52, 2019.

Ghergherehchi, C. L.; Mikesh, M.; Sengelaub, D. R.; Jackson, D. M.; Smith, T.; Nguyen, J.; Shores, J. T. \& Bittner, G. D. Polyethylene glycol (PEG) and other bioactive solutions with neurorrhaphy for rapid and dramatic repair of peripheral nerve lesions by PEG-fusion. J. Neurosci. Methods, 314:1-12, 2019

Hayat, M. A. Principles and Techniques of Electron Microscopy: Biological Applications. Cambridge, Cambridge University Press, 2000. pp.543.

Isaacs, J. E.; McDaniel, C. O.; Owen, J. R. \& Wayne, J. S. Comparative analysis of biomechanical performance of available "nerveglues". $J$. Hand Surg. Am., 33(6):893-9, 2008.

Khalifeh, J. M.; Dibble, C. F.; Dy, C. J. \& Ray, W. Z. Cost-effectiveness analysis of combined dual motor nerve transfers versus alternative surgical and nonsurgical management strategies to restore shoulder function following upper brachial plexus injury. Neurosurgery, 84(2):362-77, 2019.

Kim, P.; Kim, D. H.; Kim, B.; Choi, S. K.; Lee, S. H., Khademhosseini, A.; Langer, R. \& Suh, K. Y. Fabrication of nanostructures of polyethylene glycol for applications to protein adsorption and cell adhesion. Nanotechnology, 16(10):2420-6, 2005.

Kornfeld, T.; Vogt, P. M. \& Radtke, C. Nerve grafting for peripheral nerve injuries with extended defect sizes. Wien Med. Wochenschr., 169(910):240-51, 2019.

Lee, S. H.; Park, C. W.; Lee, S. G. \& Kim, W. K. Postoperative cervical cord compression induced by hydrogel dural sealant (DuraSeal®). Korean J. Spine, 10(1):44-6, 2013.

Lin, K. L.; Yang, D. Y.; Chu, I. M.; Cheng, F. C.; Chen, C. J.; Ho, S. P. \& Pan, H. C. DuraSeal as a ligature in the anastomosis of rat sciatic nerve gap injury. J. Surg. Res., 161(1):101-10, 2010.

Lin, Y. F.; Xie, Z.; Zhou, J.; Chen, H. H.; Shao, W. W. \& Lin, H. D. Effect of exogenous spastin combined with polyethylene glycol on sciatic nerve injury. Neural Regen. Res., 14(7):1271-9, 2019.

Molotkovets, V. Y.; Medvediev, V. V.; Korsak, A. V.; Chaikovsky, Y. B.; Marynsky, G. S. \& Tsymbaliuk, V. I. Restoration of the integrity of a transected peripheral nerve with the use of an electric welding technology. Neurophysiology, 52:31-42, 2020.

Puttaswarmy, S. V.; Bandla, A.; Fishlock, S. J.; Lee, S.; Lee, C. \& McLaughlin, J. Hydrogel as a Nerve Guide and Biocompatible Glue for Neural Applications. Cork, 2018 IEEE 18th International Conference on Nanotechnology (IEEE-NANO), 2018. pp.1-4.

Sexton, K. W.; Pollins, A. C.; Cardwell, N. L.; Del Corral, G. A.; Bittner, G. D.; Shack, R. B.; Nanney, L. B. \& Thayer, W. P. Hydrophilic polymers enhance early functional outcomes after nerve autografting. J. Surg. Res., 177(2):392-400, 2012

Tse, R. \& Ko, J. H. Nerve glue for upper extremity reconstruction. Hand Clin., 28(4):529-40, 2012.

\section{Corresponding author:}

Savosko Serhii I.

Associate professor, $\mathrm{PhD}$

department of histology and embryology

Bogomolets National Medical University

Kyiv

UKRAINE

E-mail: s.i.savosko@gmail.com

Received: 25-01-2021

Accepted: 21-02-2021 